\title{
Preprocessing procedures and supervised classification applied to a database of
}

\section{systematic soil survey}

\author{
Alan Pessoa Valadares ${ }^{1 \oplus}$, Ricardo Marques Coelho ${ }^{1 *} \odot$, Stanley Robson de Medeiros Oliveira ${ }^{2} \odot$
}

IInstituto Agronômico de Campinas/Centro de Solos e Recursos Ambientais, Av. Dr. Theodureto de Almeida Camargo, 1500 - 13075-630 - Campinas, SP - Brasil. 2Embrapa Informática Agropecuária, Av. André Tosello, 209 - 13083-886 - Campinas, SP - Brasil.

*Corresponding author <rmcoelho@iac.sp.gov.br>

Edited by: Thomas Kumke

Received May 21, 2017

Accepted May 07, 2018

\begin{abstract}
Data Mining techniques play an important role in the prediction of soil spatial distribution in systematic soil surveying, though existing methodologies still lack standardization and a full understanding of their capabilities. The aim of this work was to evaluate the performance of preprocessing procedures and supervised classification approaches for predicting map units from 1:100,000-scale conventional semi-detailed soil surveys. Sheets of the Brazilian National Cartographic System on the 1:50,000 scale, "Dois Córregos" ("Brotas" 1:100,000-scale sheet), "São Pedro" and "Laras" ("Piracicaba" 1:100,000-scale sheet) were used for developing models. Soil map information and predictive environmental covariates for the dataset were obtained from the semi-detailed soil survey of the state of São Paulo, from the Brazilian Institute of Geography and Statistics (IBGE) 1:50,000-scale topographic sheets and from the 1:750,000-scale geological map of the state of São Paulo. The target variable was a soil map unit of four types: local "soil unit" name and soil class at three hierarchical levels of the Brazilian System of Soil Classification (SiBCS). Different data preprocessing treatments and four algorithms all having different approaches were also tested. Results showed that composite soil map units were not adequate for the machine learning process. Class balance did not contribute to improving the performance of classifiers. Accuracy values of $78 \%$ and a Kappa index of 0.67 were obtained after preprocessing procedures with Random Forest, the algorithm that performed best. Information from conventional map units of semi-detailed ( $4^{\text {th }}$ order) $1: 100,000$ soil survey generated models with values for accuracy, precision, sensitivity, specificity and Kappa indexes that support their use in programs for systematic soil surveying.
\end{abstract}

Keywords: machine learning algorithms, random forest, tacit soil-landscape relationships, digital soil mapping

\section{Introduction}

One of the challenges of modeling soil classes for digital soil mapping has been to reproduce soil-landscape relationships through tacit information on conventional soil maps (Hudson, 1992). A possible strategy for overcoming this is to make the assumption that conventional soil survey databases implicitly carry information on soil-landscape relationships. Databases derived from soil surveys and those from soil predictive covariates, such as relief and parent material covariates (McBratney et al., 2003), can then be analyzed to produce patterns of soil spatial variation with techniques that belong to the field conceived as Knowledge Discovery in Databases or KDD, of which data preprocessing and data mining are essential steps in the entire process (Fayyad et al., 1996).

Optimal routines for the application of data mining techniques are far from reaching a consensus on digital soil surveys (Bagatini et al., 2016; Behrens and Scholten, 2007), but they can accelerate the generation of information on spatial distribution of soil classes. Classification algorithms such as Artificial Neural Networks (ANN) and Decision Trees (DT) have been widely used for soil survey modeling (Behrens et al., 2005; Silva et al., 2013). ANN simulates biological neural networks; its basic component, a neuron, receives input signals that are aggregated and compared to a threshold or bias of the neuron. If the aggregated signal is greater than the bias, the neuron will be activated and the output signal generated by an activation function (Zhou, 2012). Neurons are linked by weighted connections to form a network. DT uses the divide and conquer process, based on the values of information gained, to create classification rules visually similar to trees (Witten et al., 2016). Algorithms with integrated approaches are also being tested for pedological modeling. Bayesian Neural Networks, which integrate the maximization of probability estimation by Bayes' theorem with ANN (Zhou, 2012) and Random Forest, an Ensemble Method that uses the strategy of Bootstrap Aggregating to create a stronger classifier, based on random DT (Zhou, 2012; Breiman, 2001), are expected to produce very robust models (Hastie et al., 2009; Chagas et al., 2017).

The aim of this research was to evaluate the performance of data preprocessing procedures and supervised classification approaches applied to conventional map units and environmental covariates as reference data sources for predicting soil map units.

\section{Materials and Methods}

\section{Studied settings}

The research was carried out in the Geographic Information System (GIS) environment with map poly- 
gons and legend from three 1:50,000-scale sheets of the 1:100,000-scale soil survey maps of the Brotas and Piracicaba quadrangles, in the state of São Paulo, Brazil (Figure 1).

The studied region has its largest extension located on the Peripheral Depression, but also has part of it on the Basaltic Cuestas, both being geomorphological provinces of the state of São Paulo, elevation ranging from 453 to $1069 \mathrm{~m}$. On these landscapes, relief classes range from nearly level to very steep and lithology is mostly of sedimentary rocks but also, in the province of Cuestas, of basaltic rocks. Köppen's climate are Cwa and Aw (Alvares et al., 2013).

\section{Databases}

A $30-\mathrm{m}$ resolution digital elevation model generated from the Brazilian Institute of Geography and Statistics (IBGE) 1:50,000-scale toposheets provided seven predictive relief attributes: Elevation, Slope Gradient, Relief Class, Profile Curvature, Plane Curvature, Distance to Drainage, and Topographic Wetness Index (TWI). Geological Formation or Lithology, as on the geological map of the state of São Paulo (1:750,000-scale) (Perrota et al., 2005), was the $8^{\text {th }}$ predictive variable.

The target variable was either locally named Soil Units or soil classes in the $2^{\text {nd }}$ (suborder), $3^{\text {rd }}$ (great group) or $4^{\text {th }}$ (subgroup) level of the Brazilian System the Brazilian System of Soil Classification (SiBCS) (Santos et al., 2013) extracted from the Brotas (Almeida et al., 1981) and Piracicaba (Oliveira and Prado, 1989) 1:100,000-sheet soil surveys. Equivalence among map Soil Units, SiBCS subgroups, and U.S. Soil Taxonomy subgroups (Soil Survey Staff, 2014) is shown on Table 1. Mapping concepts used for Soil Units were those from the original 1:100.000-sheet soil surveys (e.g. Oliveira, 1999). Nomenclature of soil classes in the three categorical levels of SiBCS plus Soil Unit names applied to a database of soil map units enabled the structuring of four matrices of predictive attributes plus soil classes.

In order to favor machine learning of soil classes with a low number of instances, minority classes were merged, producing a larger number of instances per class. This was the case for the classes of Hydromorphic soils (Glei), Orthents (Litólicos), certain Alfisols with abrupt textural changes (Diamante), and Spodosols (Podzóis).

\section{Data mining}

\section{Preprocessing}

Efficiency of the procedures for variable discretization, data selection, under- and oversampling, class balancing, and variable selection (Table 2) was evaluated using the Weka software, version 3.8 .0 by "Hold-Out" (Supplied Test Set - 2/3 for training, 1/3 for test).

The predictive variable "relief class" was obtained by discretization of the slope gradient into the following classes: $0-4,4-8,8-20,20-45,45-75$, > $75 \%$. These variables (slope gradient and relief class) were used simultaneously in both the continuous and discrete forms in data matrices. Discretization of continuous predictive variables in arbitrary classes was also carried out for profile curvature and plane curvature. The discrete classes described above can better represent the hydrodynamic behavior of landscapes than continuous variables. Discretization was tested for the variables TWI and distance to drainage using intervals of equal ranges and equal frequencies. The adopted interval for defining

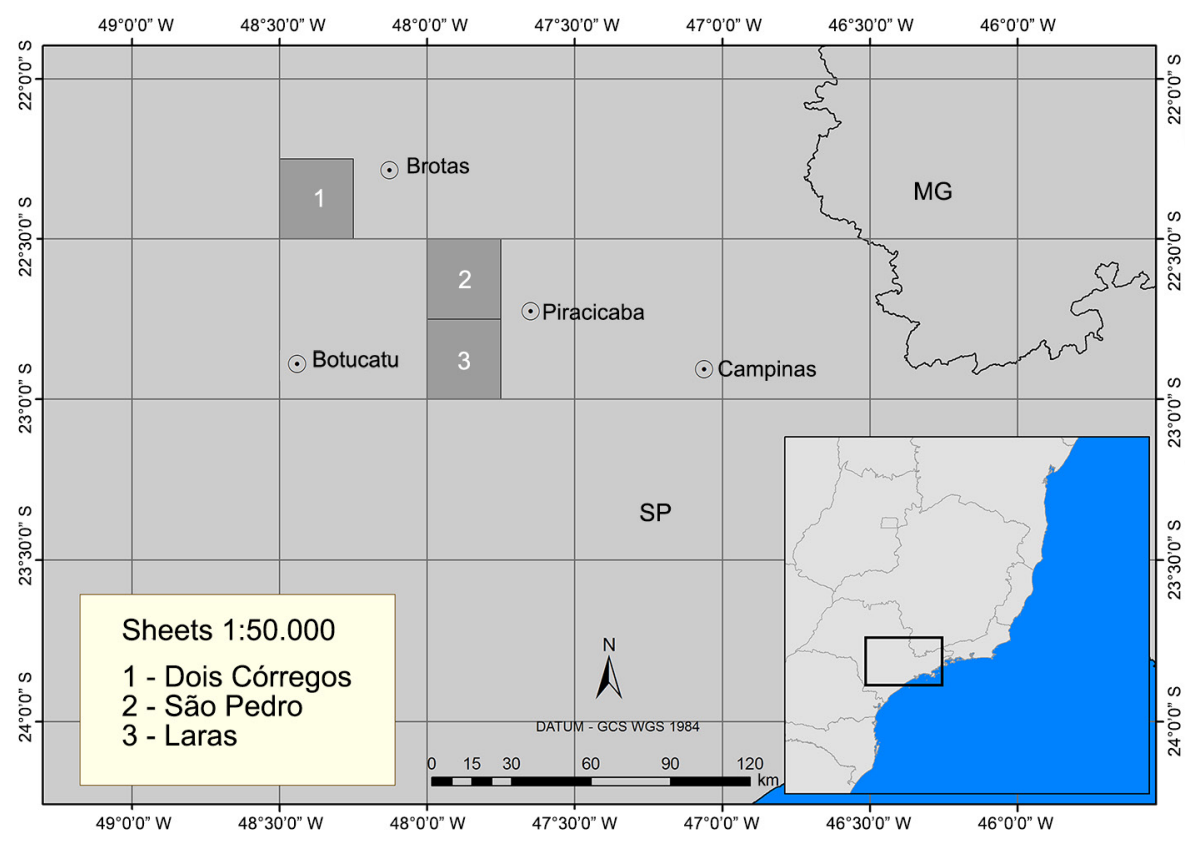

Figure 1 - Sheets on 1:50,000 scale from study area (São Paulo, Brazil). 
Table 1 - Equivalence of mapped Soil Units to soil classes of the Brazilian System of Soil Classification (SiBCS) and U.S. Soil Taxonomy.

\begin{tabular}{|c|c|c|}
\hline Soil Units & Soil classes at the $4^{\text {th }}$ level of the SiBCS a & U.S. Soil Taxonomy \\
\hline Alva & PVAd e PVAe abrúptico, A moderado, textura arenosa/média & Sandy over Fine-loamy, Arenic and Typic Paleudult \\
\hline Areia Quartzosa & RQo típico, A moderado & Typic Quartzipsamment \\
\hline Baguari & $\begin{array}{l}\text { PVAd e PVAe típico e abrúptico, A moderado, textura média e média/ } \\
\text { argilosa }\end{array}$ & Fine-loamy, Typic Kandiudult \\
\hline Barão Geraldo & LVdf típico, A moderado, textura argilosa e muito argilosa & Fine and Very Fine, Rhodic Hapludox \\
\hline Campestre & PVe nitossólico e NVe típico, A moderado, textura argilosa/muito argilosa & Fine, Rhodic Kandiudult and Kandiudalf \\
\hline Canela & PVd e PVAd típico, A moderado, textura média e média/argilosa & Fine-loamy over Fine, Typic Kandiudult \\
\hline Coqueiro & LVAd psamítico e típico, A moderado e fraco, textura média & Coarse-loamy, Typic Hapludox \\
\hline Diamante & SXe e SXd típico e vertissólico, A moderado, textura média/argilosa & Fine-loamy over Fine, Vertic, Albaquic and Typic Hapludalf \\
\hline Engenho & MTf e MTo típico, textura argilosa & Very Fine and Fine, Typic Paleudoll \\
\hline Estruturada & NVef e NVdf típico, A moderado, textura argilosa e muito argilosa & Very Fine and Fine, Kandiudalfic Eutrudox \\
\hline Hidromórficos & $\begin{array}{l}\text { GXvd, GXve, GXbd e GXbe típico, A moderado e proeminente, textura } \\
\text { argilosa }\end{array}$ & Fine, Aquept, Aquent, Aquox, Aquult, Aqualf \\
\hline Hortolândia & LVd típico, A moderado, textura média & Fine Loamy, Rhodic Hapludox \\
\hline Itaguaçu & NVdf latossólico, A moderado, textura argilosa e muito argilosa & Fine and Very Fine, Kandiudalfic Eutrudox and Rhodic Kandiudox \\
\hline Laranja Azeda & LVAd típico, A moderado, textura média & Fine-loamy, Typic Hapludox \\
\hline Limeira & LVd típico, A moderado, textura argilosa e muito argilosa & Very Fine and Fine, Rhodic Hapludox \\
\hline Litólicos & RLe e RLm típicos, A moderado e chernozêmico, textura média & Loamy, Lithic Udorthent \\
\hline Monte Cristo & $\begin{array}{l}\text { PVAd e PVAe abrúptico e arênico abrúptico, A moderado, textura } \\
\text { arenosa/média e média/argilosa }\end{array}$ & $\begin{array}{l}\text { Sandy over Fine-loamy and Sandy over Fine, Arenic Kandiudult } \\
\text { and Arenic Kandiudalf }\end{array}$ \\
\hline Olaria & NXd típico, A moderado, textura argilosa e muito argilosa & Fine and Very Fine, Typic and Rhodic Kandiudult \\
\hline Podzóis & ESKo típico, textura arenosa/média & Sandy over Coarse-loamy, Humod \\
\hline Ribeirão Preto & LVef típico, A moderado, textura argilosa e muito argilosa & Fine and Very Fine, Rhodic Eutrudox \\
\hline Santa Cruz & $\begin{array}{l}\text { PVAd e PVAe abrúptico, A moderado, textura média/argilosa media/muito } \\
\text { argilosa e argilosa/muito argilosa }\end{array}$ & Fine-loamy over Fine, Typic Kandiudult and Typic Kandiudalf \\
\hline Santana & NXe chernossólico, textura média/argilosa & Fine-loamy over Fine, Typic Paleudoll \\
\hline São Lucas & LAd e LVAd psamítico, A moderado, textura média & Coarse-loamy, Typic Hapludox and Kandiudox \\
\hline Serrinha & $\begin{array}{l}\text { PVAd, PVAe, PAd e PAe arênico abrúptico, A moderado e fraco, textura } \\
\text { arenosa/média }\end{array}$ & $\begin{array}{l}\text { Sandy over Fine-loamy, Arenic Paleudult, Grossarenic Paleudult, } \\
\text { Arenic Paleudalf and Grossarenic Paleudalf }\end{array}$ \\
\hline Sete Lagoas & CYbd e CYbe típico, A moderado e proeminente, textura argilosa e média & Fine and Fine-loamy, Fluventic and Typic Dystrudept \\
\hline Taquaraxim & CXbd e CXbe típico, A moderado e proeminente, textura média e argilosa & Fine-loamy, Typic Dystrudept \\
\hline Três Barras & LAd úmbrico, textura media & Coarse- and Fine-loamy, Xanthic and Typic Hapludox \\
\hline
\end{tabular}

aAbreviations as in the Brazilian System of Soil Classification (SiBCS) (Santos et al., 2013).

Table 2 - Summary of preprocessing procedures.

\begin{tabular}{ll}
\hline Procedures & \multicolumn{1}{c}{ Importance /Application } \\
\hline Stratified sampling & Stratified data sampling separating training and testing datasets in the reference area. \\
Data Selection & Identification and exclusion of inconsistent information. \\
Discretization & Transformation of continuous quantitative variables into categorical ones. \\
Undersampling & Resampling by gradual elimination of information from the majority classes in the training of unbalanced classes. \\
Oversampling & Replication sampling of minority classes in training unbalanced classes. \\
Class Balancing & Resampling with standardization of the distribution (frequency) of prediction classes. \\
Selection of Variables & Evaluation of the predictive power of each explanatory variable and elimination of those detrimental to machine learning. \\
\hline
\end{tabular}

criteria was the one that best improved the performance of the classifier, as evaluated by the "Hold-Out" method.

Resampling procedures were evaluated in order to improve the predictive power of the models in the less representative soil classes in the reference area. Undersampling, oversampling, and class balancing procedures were applied to $2 / 3$ of the map unit database. Resampling was applied at three levels, zero $(0.0)$, representing the original distribution of the data, one (1.0), the balanced distribution of soil classes, and 0.5 , a distribution involving undersampling of majority classes and overs- ampling of minority classes. The test database for these procedures was $1 / 3$ of the instances using the "HoldOut" method (Supplied Test Set).

Ranking predictive variables by importance was carried out by chi-square $\left(\chi^{2}\right)$ and information gain, two commonly used feature-selection methods.

\section{Soil class prediction}

Preprocessing procedures were evaluated using four algorithms, Random Forest, J48, MLP and Bayes Net to explore their capabilities to predict soil map units 
Table 3 - Algorithms used for supervised classification.

\begin{tabular}{lcl}
\hline Algorithm (classifier) & Reference & \multicolumn{1}{c}{ Type of approach } \\
\hline J.48 (C4.5) & Quinlan (1993) & DecisionTree (divide and conquer process based on data information gain) \\
Random Forest & Breiman (2001) & Ensemble (bootstrap aggregating based on random decision trees) \\
Multi-Layer Perceptron & Si et al. (2003) & Artificial Neural Networks (transfer functions based on input signal, connections weight and neuron bias) \\
Bayes Net & Hall et al. (2009) & Bayesian Classifiers (integrates Bayesian probability function to ANN) \\
\hline
\end{tabular}

(Table 3). Performance of classifiers for each prediction class was evaluated by accuracy, true and false positive rates (TPR and FPR), and by the area under the curve (Bradley, 1997). To evaluate the global performance of classifiers, we used global accuracy (Weiss and Zhang, 2003), weighted mean precision, weighted average of the true positive (weighted mean sensitivity) and the false positive (one minus weighted mean specificity), and the Kappa index (Cohen, 1960).

\section{Results}

\section{Preprocessing procedures}

\section{Discretization}

Profile and plane curvature performed better as discrete variables, whereas elevation, distance to drainage and topographic wetness index (TWI) had better performance as continuous variables. Slope had better performance used in conjunction with its discrete form (relief class). Small differences in performance were considered for pre-selecting the type of predictive attribute. The best adjustment results in these cases are shown in Table 4.

Accuracy values were around $50 \%$ and Kappa indices between 0.35 and 0.45 , meaning fair and good agreement (Table 4). The weighted averages of true positive rates (average sensitivity) for the best models were between $42 \%$ and $50 \%$ (Table 4). The specificity of the rules generated by the models was high, indicated by the low mean of false positive rates, with values from 5 $\%$ to $9 \%$ (Table 4 ).

\section{Data selection}

Data selection was fundamental to the acceptance of models generated by all evaluated algorithms. Accuracy ranged from $65 \%$ to $78 \%$, and the Kappa index from 0.50 to 0.67 , representing good and very good agreement (Table 5). Composite map units (soil associations and soil complexes) from conventional soil maps showed inconsistency (reduction of predictive performance) and were therefore removed.

Weighted average of true positive rates (TPR) (mean sensitivity) for models generated by conventional map units were between $65 \%$ and $68 \%$ (Table 5). Weighted average of false positive rates (FPR) ranged from 6 to $16 \%$.

Resampling procedures (subsampling, class balancing and oversampling) did not favor model performance. There was a considerable reduction in global
Table 4 - Best algorithm performances after discretization procedures. Classification in soil unit. Accuracy = Global Accuracy; TPR $=$ weighted average of true positive rates; FPR $=$ weighted average of false positive rates.

\begin{tabular}{lrrrrrr}
\hline Algorithms $^{\mathrm{a}}$ & Accuracy & Error & Precision & TPR & FPR & Kappa \\
\cline { 2 - 6 } & & & & & & \\
\cline { 2 - 6 } & 50.19 & 49.81 & 48.10 & 50.20 & 5.50 & 44.70 \\
J48 & 47.87 & 52.13 & 44.90 & 47.90 & 8.80 & 39.76 \\
MLP & 42.52 & 57.48 & 37.30 & 42.50 & 6.50 & 35.78 \\
\hline Bayes Net & &
\end{tabular}

aAlgorithm Random Forest could not be used with this dataset due to computational limitations.

Table 5 - Performance of the algorithms after discretization and data selection. Classification in soil units. Accuracy = Global Accuracy; Precision $=$ weighted average precision; TPR $=$ weighted average of true positive rates; FPR = weighted average of false positive rates.

\begin{tabular}{lcccccc}
\hline Algorithms & Accuracy & Error & Precision & TPR & FPR & Kappa \\
\cline { 2 - 7 } & \multicolumn{7}{c}{} & \multicolumn{2}{c}{$\%$} & & & \\
\cline { 2 - 7 } Random Forest & 78.13 & 21.87 & 77.70 & 78.10 & 12.80 & 67.0 \\
J48 & 76.09 & 23.91 & 75.30 & 76.10 & 13.50 & 64.0 \\
MLP & 71.64 & 28.36 & 71.00 & 71.60 & 15.70 & 57.0 \\
Bayes Net & 65.75 & 34.25 & 65.00 & 65.70 & 15.30 & 50.0 \\
\hline
\end{tabular}

accuracy and class precision as soil unit distribution approached the fully balanced distribution (1.0) (Table 6). Databases always produced models with better performance when they were not submitted to resampling procedures.

Results for variable selection showed that all the predictive variables were important for the generated models, with classifier performance reduction as any predictive variable was removed from databases. Evaluation of variables by chi-square $\left(\chi^{2}\right)$ and information gain methods showed attributes in the following descending order of predictive power: elevation, geology, distance to drainage, slope gradient, relief class, topographic wetness index (TWI), profile curvature and plane curvature (Table 7).

\section{Algorithms}

Global model evaluation used the following metrics: accuracy (overall accuracy), precision, weighted mean of true positive rates, weighted mean of false positive rates and Kappa index (Table 5). The algorithm with the best overall performance was Random Forest, with an Ensemble Method for Prediction approach that generated 20 decision trees for the creation of models. 
Table 6 - Performance of the algorithms for holdout accuracy (2/3 training and $1 / 3$ test) after subsampling (0.5), class balancing (1.0) and resampling keeping the original data distribution (0.0).

\begin{tabular}{|c|c|c|c|c|c|c|c|c|c|}
\hline & \multicolumn{3}{|c|}{ Random Forest } & \multicolumn{3}{|c|}{$\mathrm{J} 48$} & \multicolumn{3}{|c|}{ Bayes Net } \\
\hline & 1.0 & 0.5 & 0.0 & 1.0 & 0.5 & 0.0 & 1.0 & 0.5 & 0.0 \\
\hline & \multicolumn{9}{|c|}{ Weighted average precision (\%) } \\
\hline & 72.10 & 75.80 & 76.50 & 68.80 & 71.40 & 71.70 & 40.68 & 61.46 & 65.00 \\
\hline Soil units & \multicolumn{9}{|c|}{ Precision per Soil Unit } \\
\hline Alva & 0.131 & 0.206 & 0.394 & 0.098 & 0.128 & 0.372 & 0.041 & 0.159 & 0.756 \\
\hline Areia Quartzosa & 0.730 & 0.803 & 0.805 & 0.699 & 0.758 & 0.755 & 0.696 & 0.738 & 0.736 \\
\hline Baguari & 0.433 & 0.701 & 0.754 & 0.360 & 0.564 & 0.617 & 0.161 & 0.347 & 0.427 \\
\hline Barão Geraldo & 0.563 & 0.663 & 0.717 & 0.517 & 0.597 & 0.631 & 0.155 & 0.179 & 0.195 \\
\hline Campestre & 0.282 & 0.495 & 0.648 & 0.211 & 0.346 & 0.453 & 0.068 & 0.123 & 0.291 \\
\hline Canela & 0.761 & 0.803 & 0.782 & 0.709 & 0.740 & 0.731 & 0.501 & 0.558 & 0.589 \\
\hline Coqueiro & 0.205 & 0.455 & 0.746 & 0.147 & 0.260 & 0.378 & 0.036 & 0.061 & 0.077 \\
\hline Diamante & 0.500 & 0.429 & 0.000 & 0.231 & 0.292 & 0.000 & 0.000 & 0.000 & 0.000 \\
\hline Engenho & 0.071 & 0.127 & 0.231 & 0.042 & 0.079 & 0.072 & 0.041 & 0.071 & 0.067 \\
\hline Estruturada & 0.441 & 0.565 & 0.639 & 0.327 & 0.434 & 0.506 & 0.082 & 0.111 & 0.127 \\
\hline Hidromórficos & 0.423 & 0.587 & 0.646 & 0.406 & 0.523 & 0.570 & 0.269 & 0.330 & 0.356 \\
\hline Hortolândia & 0.666 & 0.680 & 0.699 & 0.577 & 0.585 & 0.584 & 0.289 & 0.320 & 0.380 \\
\hline Itaguaçu & 0.732 & 0.688 & 0.700 & 0.673 & 0.660 & 0.560 & 0.087 & 0.313 & 0.167 \\
\hline Laranja Azeda & 0.370 & 0.584 & 0.718 & 0.291 & 0.457 & 0.590 & 0.160 & 0.326 & 0.574 \\
\hline Limeira & 0.743 & 0.773 & 0.747 & 0.695 & 0.728 & 0.718 & 0.510 & 0.573 & 0.575 \\
\hline Litólicos & 0.371 & 0.614 & 0.653 & 0.300 & 0.481 & 0.525 & 0.187 & 0.368 & 0.467 \\
\hline Monte Cristo & 0.720 & 0.735 & 0.748 & 0.632 & 0.642 & 0.668 & 0.238 & 0.285 & 0.376 \\
\hline Olaria & 0.350 & 0.553 & 0.655 & 0.259 & 0.398 & 0.529 & 0.098 & 0.194 & 0.277 \\
\hline Podzóis & 0.053 & 0.121 & 0.250 & 0.038 & 0.045 & 0.083 & 0.027 & 0.056 & 0.000 \\
\hline Ribeirão Preto & 0.371 & 0.394 & 0.381 & 0.241 & 0.263 & 0.212 & 0.096 & 0.129 & 0.089 \\
\hline Santa Cruz & 0.461 & 0.680 & 0.699 & 0.420 & 0.581 & 0.589 & 0.321 & 0.463 & 0.486 \\
\hline Santana & 0.676 & 0.800 & 0.867 & 0.430 & 0.630 & 0.565 & 0.108 & 0.350 & 0.579 \\
\hline São Lucas & 0.144 & 0.341 & 0.526 & 0.113 & 0.199 & 0.277 & 0.049 & 0.063 & 0.054 \\
\hline Serrinha & 0.862 & 0.806 & 0.792 & 0.840 & 0.794 & 0.780 & 0.762 & 0.742 & 0.744 \\
\hline Sete Lagoas & 0.410 & 0.463 & 0.532 & 0.436 & 0.493 & 0.592 & 0.236 & 0.323 & 0.393 \\
\hline Taquaraxim & 0.587 & 0.666 & 0.774 & 0.516 & 0.585 & 0.674 & 0.363 & 0.418 & 0.449 \\
\hline Três Barras & 0.902 & 0.893 & 0.904 & 0.868 & 0.860 & 0.868 & 0.698 & 0.688 & 0.728 \\
\hline
\end{tabular}

Table 7 - Assessment of covariates by their prediction power based on information gain and chi-square $\left(\chi^{2}\right)$.

\begin{tabular}{lcr}
\hline Covariates & Information Gain & \multicolumn{1}{c}{$\chi^{2}$} \\
\hline Elevation & 0.885 & $2,141,866$ \\
Geology & 0.774 & $1,258,271$ \\
Distance to Drainage & 0.219 & 270,550 \\
Slope Gradient & 0.108 & 168,237 \\
Relief Class & 0.074 & 74,552 \\
TWI & 0.054 & 58,413 \\
Profile Curvature & 0.049 & 45,768 \\
Plane Curvature & 0.028 & 23,355 \\
\hline
\end{tabular}

Algorithm J48 (Decision Tree) presented results close to those of Random Forest, but always inferior, whereas the algorithms MLP (Artificial Neural Networks) and Bayes Net (Bayesian Neural Networks) showed worse performance, despite Kappa indexes of 0.57 and 0.50, respectively (Table 5).

Precision per class was evaluated in order to differentiate the performance of the models of each algorithm per predicted class. Results showed that preci- sion per class followed the results for global model evaluation (Table 8). In general, models with better overall performance showed better accuracy performance per prediction class. Exceptions occurred for Campestre and Baguari soil units, where the accuracy of MLP algorithm was greater than that obtained by J48. For Sete Lagoas, Engenho, Alva and Diamante soil units, the model generated by the J48 algorithm showed better performance than that developed by Random Forest. Precision for Itaguaçu, Santana and Alva units was greater in the model generated by Bayes Net algorithm than by MLP, in which they obtained zero precision. The São Lucas unit had better precision in the model generated by MLP algorithm (Table 8).

\section{Assessment of categorical levels of SiBCS}

As for the evaluated categorical levels of SiBCS (Suborder, Great Group and Subgroup), there was little difference in accuracy and Kappa between the categories. A small decrease in performance was associated with an increase in the detail of the categorical level, the 
algorithm MLP (Artificial Neural Networks) was an exception, and had better performance with classification at the $3^{\text {rd }}$ categorical level of SiBCS (Great Group) (Table 9). Predictions of conventional map units classified by the Brazilian System of Soil Classification (SiBCS) (Table 9) were very similar to classification by soil units (Table $5)$, even though slightly better.

Results for the weighted average of true positive rates in each class by the algorithm of best performance with classification at the $4^{\text {th }}$ level (Subgroup) of SiBCS was $78 \%$, indicating good average sensitivity (average chance of the classifier to hit a particular class) (Table

Table 8 - Precision of algorithms evaluated by Hold-Out (2/3 training and $1 / 3$ test) in each soil map unit and classification in Soil Units.

\begin{tabular}{lcccc}
\hline Soil Unit & Random Forest & J48 & MLP & Bayes Net \\
\hline Alva & 0.411 & 0.550 & 0.000 & 0.806 \\
Areia Quartzosa & 0.826 & 0.809 & 0.760 & 0.736 \\
Baguari & 0.778 & 0.708 & 0.709 & 0.441 \\
Barão Geraldo & 0.726 & 0.670 & 0.510 & 0.205 \\
Campestre & 0.678 & 0.552 & 0.644 & 0.276 \\
Canela & 0.800 & 0.749 & 0.624 & 0.591 \\
Coqueiro & 0.744 & 0.612 & 0.000 & 0.000 \\
Diamante & 0.333 & 0.600 & 0.000 & 0.000 \\
Engenho & 0.000 & 0.083 & 0.000 & 0.000 \\
Estruturada & 0.687 & 0.586 & 0.487 & 0.120 \\
Hidromórficos & 0.656 & 0.625 & 0.419 & 0.356 \\
Hortolândia & 0.727 & 0.645 & 0.582 & 0.376 \\
Itaguaçu & 0.721 & 0.596 & 0.000 & 0.154 \\
Laranja Azeda & 0.728 & 0.640 & 0.689 & 0.578 \\
Limeira & 0.758 & 0.751 & 0.587 & 0.586 \\
Litólicos & 0.700 & 0.640 & 0.559 & 0.477 \\
Monte Cristo & 0.783 & 0.694 & 0.621 & 0.375 \\
Olaria & 0.693 & 0.585 & 0.425 & 0.322 \\
Podzóis & 0.667 & 0.200 & 0.000 & 0.000 \\
Ribeirão Preto & 0.494 & 0.338 & 0.000 & 0.075 \\
Santa Cruz & 0.718 & 0.695 & 0.643 & 0.489 \\
Santana & 0.947 & 0.735 & 0.000 & 0.481 \\
São Lucas & 0.574 & 0.409 & 0.804 & 0.067 \\
Serrinha & 0.792 & 0.781 & 0.753 & 0.742 \\
Sete Lagoas & 0.566 & 0.635 & 0.624 & 0.412 \\
Taquaraxim & 0.790 & 0.714 & 0.602 & 0.453 \\
Três Barras & 0.911 & 0.889 & 0.781 & 0.733 \\
\hline & & & &
\end{tabular}

Table 9 - Best performance of the algorithms evaluated by Hold-Out $\left(2 / 3\right.$ training and $1 / 3$ test), with classification in the $2^{\text {nd }}, 3^{\text {rd }}$ and $4^{\text {th }}$ categorical levels of SiBCS.

\begin{tabular}{|c|c|c|c|c|c|c|}
\hline \multirow{3}{*}{ Algorithms } & \multicolumn{3}{|c|}{ SiBCS hierarchical levels } & \multicolumn{3}{|c|}{ SiBCS hierarchical levels } \\
\hline & $2^{\text {nd }}$ & $3^{\text {rd }}$ & $4^{\text {th }}$ & $2^{\text {nd }}$ & $3^{\text {rd }}$ & $4^{\text {th }}$ \\
\hline & \multicolumn{3}{|c|}{ Accuracy } & \multicolumn{3}{|c|}{ Kappa } \\
\hline & & & - & 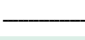 & & \\
\hline Random Forest & 78.69 & 78.61 & 78.18 & 67.90 & 67.81 & 67.42 \\
\hline $\mathrm{J} 48$ & 76.77 & 76.62 & 76.25 & 65.00 & 64.89 & 64.57 \\
\hline MLP & 71.74 & 72.22 & 71.45 & 57.42 & 57.78 & 57.42 \\
\hline Bayes Net & 66.71 & 66.37 & 65.84 & 51.28 & 50.86 & 50.42 \\
\hline
\end{tabular}

10). The weighted mean false positive rates were $13 \%$, indicating that the classification rules also showed good average specificity (average chance of the classifier failing in a given class) due to the low number of false positive occurrences (Table 10).

The lowest sensitivity values were for "Planossolos" (Alfisols with abrupt textural changes), "Espodossolos" (Spodosols), "Chernossolos" (Mollisols), "Latossolos Amarelos and Vermelho-Amarelos psamíticos" (coarse- and fine-loamy, Xanthic and Typic Oxisols), and "Latossolos Vermelhos Eutroférricos" (Rhodic Eutrudox). Rules created for the remaining classes showed good sensitivity, the best results being obtained for "Argissolos Vermelho-Amarelos" (Arenic and Grossarenic Paleudults and Paleudalfs) and "Latossolos Amarelos Distróficos úmbricos, textura media" (coarse- and fineloamy Typic Hapludox), with sensitivity values close to 0.9 (Table 10).

The low false positive rates indicate that the rules created by the Random Forest algorithm (committee of 20 decision trees) showed good specificity with the conventional map units and classification at the $4^{\text {th }}$ level (Subgroup) of the SiBCS (Table 10). Values obtained for the area under the curve were quite satisfactory, ranging from 0.7 to 1.0 (Table 10).

\section{Discussion}

Preprocessing procedures were extremely important to improving the performance of the models generated by the algorithms. When evaluating data selection, certain information showed inconsistent for machine learning (Han et al., 2011), as they drastically reduced the performance of the evaluated models in supervised classification. This was observed for map units of soil associations and soil complexes. Composite map units (soil associations or complexes) are supposed to carry greater complexity of soil forming factors than those present in soil consociations. Thus, as soil forming factors relief and parent material were used for deriving covariates for soil prediction, this greater complexity could affect the results. Exclusion of composite map units from the training set does not preclude to map areas with features associated with these map units since soil complex and soil associations, composed of two or more soil consociations, are represented by the single unit of the main consociation in the training set. Reducing complexity of predictive covariates has been a successful strategy for improving the prediction of soil map units (Ten Caten et al., 2012).

To deal with the substantial amount of information extracted from the training areas $(1,013,329$ instances after preprocessing) we used the Hold-Out method, $2 / 3$ for training and $1 / 3$ for model testing, increasing the amount of information for training and testing the models, optimizing the analysis procedure in relation to computational capacity or processing time. 
Table 10 - Performance per class of the Random Forest algorithm. Classification in the 4th level (Subgroup) of SiBCS. TP = true positive rate; $\mathrm{FP}=$ false positive rate; $\mathrm{AUC}=$ area under th e curve.

\begin{tabular}{|c|c|c|c|c|c|}
\hline TP & FP & Precision & AUC & Soil class ${ }^{\mathrm{a}}$ & U.S. Soil Taxonomy \\
\hline 0.701 & 0.001 & 0.811 & 0.972 & $\begin{array}{l}\text { CXbd e CXbe típicos, A moderado e proeminente, textura média e } \\
\text { argilosa }\end{array}$ & Fine-loamy, Typic Dystrudept \\
\hline 0.683 & 0.006 & 0.578 & 0.990 & $\begin{array}{l}\text { CYbd e CYbe típicos, A moderado e proeminente, textura argilosa } \\
\text { e média }\end{array}$ & Fine and Fine-loamy, Fluventic and Typic Dystrudept \\
\hline 0.000 & 0.000 & 0.000 & 0.707 & ESKo típico, textura arenosa/média & Sandy over Coarse-loamy, Humod \\
\hline 0.601 & 0.006 & 0.663 & 0.973 & $\begin{array}{l}\text { GXvd, GXve, GXbd e GXbe típicos, A moderado e proeminente, } \\
\text { textura argilosa }\end{array}$ & Fine, Aquept, Aquent, Aquox, Aquult, Aqualf \\
\hline 0.180 & 0.002 & 0.564 & 0.860 & LAd e LVAd psamíticos, A moderado & Coarse-loamy, Typic Hapludox and Kandiudox \\
\hline 0.902 & 0.001 & 0.922 & 0.997 & LAd úmbrico, textura média & Coarse- and Fine-loamy, Xanthic and Typic Hapludox \\
\hline 0.300 & 0.000 & 0.770 & 0.903 & LVAd psamítico e típico, A moderado e fraco, textura média & Coarse-loamy, Typic Hapludox \\
\hline 0.617 & 0.001 & 0.739 & 0.965 & LVAd típico, A moderado, textura média & Fine-loamy, Typic Hapludox \\
\hline 0.850 & 0.005 & 0.759 & 0.994 & LVd típico, A moderado, textura argilosa e muito argilosa & Very Fine and Fine, Rhodic Hapludox \\
\hline 0.617 & 0.002 & 0.737 & 0.986 & LVd típico, A moderado, textura média & Fine Loamy, Rhodic Hapludox \\
\hline 0.682 & 0.002 & 0.738 & 0.987 & LVdf típico, A moderado, textura argilosa e muito argilosa & Fine and Very Fine, Rhodic Hapludox \\
\hline 0.212 & 0.000 & 0.607 & 0.913 & LVef típico, A moderado, textura argilosa ou muito argilosa & Fine and Very Fine, Rhodic Eutrudox \\
\hline 0.010 & 0.000 & 0.143 & 0.743 & MTf e MTo típicos, textura argilosa & Very Fine and Fine, Typic Paleudoll \\
\hline 0.611 & 0.000 & 0.733 & 1.000 & NVdf latossólico, A moderado, textura argilosa ou muito argilosa & $\begin{array}{l}\text { Fine and Very Fine, Kandiudalfic Eutrudox and Rhodic } \\
\text { Kandiudox }\end{array}$ \\
\hline 0.546 & 0.001 & 0.655 & 0.964 & NVef e NVdf típicos, A moderado, textura argilosa e muito argilosa & Very Fine and Fine, Kandiudalfic Eutrudox \\
\hline 0.527 & 0.001 & 0.669 & 0.943 & NXd típico, A moderado, textura argilosa e muito argilosa & Fine and Very Fine, Typic and Rhodic Kandiudult \\
\hline 0.759 & 0.000 & 0.837 & 0.991 & NXe chernossólico, textura média/argilosa & Fine-loamy over Fine, Typic Paleudoll \\
\hline 0.707 & 0.002 & 0.763 & 0.988 & $\begin{array}{l}\text { PVAd e PVAe abrúpticos e arênico abrúpticos, A moderado, textura } \\
\text { arenosa/média e média/argilosa }\end{array}$ & $\begin{array}{l}\text { Sandy over Fine-loamy and Sandy over Fine, Arenic } \\
\text { Kandiudult and Arenic Kandiudalf }\end{array}$ \\
\hline 0.572 & 0.000 & 0.490 & 0.998 & PVAd e PVAe abrúpticos, A moderado, textura arenosa/média & Sandy over Fine-loamy, Arenic and Typic Paleudult \\
\hline 0.571 & 0.021 & 0.714 & 0.931 & $\begin{array}{l}\text { PVAd e PVAe abrúpticos, A moderado, textura média/argilosa, } \\
\text { média/muito argilosa e argilosa/muito argilosa }\end{array}$ & $\begin{array}{l}\text { Fine-loamy over Fine, Typic Kandiudult and Typic } \\
\text { Kandiudalf }\end{array}$ \\
\hline 0.604 & 0.006 & 0.769 & 0.943 & $\begin{array}{l}\text { PVAd e PVAe típico e abrúpticos, A moderado, textura média e } \\
\text { média/argilosa }\end{array}$ & Fine-loamy, Typic Kandiudult \\
\hline 0.902 & 0.235 & 0.793 & 0.907 & $\begin{array}{l}\text { PVAd, PVAe, PAd e PAe arênicos abrúpticos, A moderado e fraco, } \\
\text { textura arenosa/média }\end{array}$ & $\begin{array}{l}\text { Sandy over Fine-loamy, Arenic Paleudult, Grossarenic } \\
\text { Paleudult, Arenic Paleudalf and Grossarenic Paleudalf }\end{array}$ \\
\hline 0.836 & 0.003 & 0.788 & 0.994 & PVd e PVAd típicos, A moderado, textura média e média/argilosa & Fine-loamy over Fine, Typic Kandiudult \\
\hline 0.412 & 0.001 & 0.677 & 0.947 & $\begin{array}{l}\text { PVe nitossólico e NVe típico, A moderado, textura argilosa/muito } \\
\text { argilosa }\end{array}$ & Fine, Rhodic Kandiudult and Kandiudalf \\
\hline 0.518 & 0.011 & 0.702 & 0.916 & RLe e RLm típicos, A moderado e chernozemico, textura média & Loamy, Lithic Udorthent \\
\hline 0.757 & 0.040 & 0.829 & 0.956 & RQo típico, A moderado & Typic Quartzipsamment \\
\hline 0.000 & 0.000 & 0.000 & 0.964 & $\begin{array}{l}\text { SXe e SXd típicos e vertissólicos, A moderado, textura média/ } \\
\text { argilosa }\end{array}$ & $\begin{array}{l}\text { Fine-loamy over Fine, Vertic, Albaquic and Typic } \\
\text { Hapludalf }\end{array}$ \\
\hline 0.782 & 0.128 & 0.777 & 0.929 & Weighted average & \\
\hline
\end{tabular}

Results from class balancing followed the pattern found by Crivelenti et al. (2009), with a decrease in performance of classifiers after class balancing (training in equal frequency classes). This indicates that, in this case, undersampling majority classes was detrimental to the machine learning process, probably due to the failure of classifiers to learn important relationships.
Therefore, even though an improvement in the prediction of minority classes after balancing was expected, class balancing was detrimental to the overall performance of the models.

Random Forest, a supervised classification method with ensemble approach, produced models with the best performances, similar to the findings of Dias et al. (2016), 
and Chagas et al. (2017), surpassing J.48, a decision tree algorithm. This opposes the findings of Ten Caten et al. (2013), in terms of accuracy and kappa indexes above $70 \%$ when using decision trees in smaller datasets than those studied here. The use of Bootstrap Aggregating (Bagging) in the Random Forest algorithm shows advantages due to the combination of classifiers (Zhou, 2012).

The high performance of the model generated by the Random Forest algorithm at the $4^{\text {th }}$ level (Subgroup) of SiBCS (accuracy above $78 \%$ and kappa index above $67 \%$ ) indicates that the approach has great potential for producing digital pedological maps compatible to medium and high intensity reconnaissance ( $4^{\text {th }}$ order) soil surveys.

Some of the minority classes were better predicted by models with lower global performance. However, in all cases the information gain with these individual classes was not significant enough to improve the overall performance of the models. This fact may be due, in the main, to the prevalence of certain classes in the training area, which resulted in assigning great weight to small decreases in the performance of these majority classes. The high accuracy level in most of the predicted classes is indicative of the high predictive power of the models tested.

\section{Conclusions}

Composite soil map units (soil complex and soil associations) proved to be inadequate for the machine learning process, since their exclusion from the training dataset improved overall prediction.

When modeling soil map units for pedological mapping, training on unbalanced databases outperformed training on balanced databases, showing no need for class balancing for machine learning on the studied dataset.

The Random Forest algorithm had good performance for soil class prediction and, though requiring preprocessing procedures, outscored algorithms of different approaches, such as single Decision Trees, Artificial Neural Networks and Bayesian Classification.

The applied predictive variables (terrain attributes and geology) trained on 1:100,000 soil survey maps showed excellent performance for predicting soil map unit distribution, and can be used to create digital pedological maps consistent with high intensity reconnaissance soil survey $\left(4^{\text {th }}\right.$ order $)$ maps.

\section{Authors' Contributions}

Conceptualization: Coelho, R.M.; Valadares, A.P. Data acquisition: Valadares, A.P.; Coelho, R.M.; Oliveira, S.R.M. Data analysis: Valadares, A.P.; Oliveira, S.R.M. Design of methodology: Coelho, R.M.; Valadares, A.P.; Oliveira, S.R.M. Software development: Valadares, A.P.; Oliveira, S.R.M. Writing and Editing: Valadares, A.P.; Coelho, R.M.; Oliveira, S.R.M.

\section{References}

Almeida, C.L.F.; Oliveira, J.B.; Prado, H. 1981. Semi detailed Soil Survey of the State of São Paulo: Brotas Sheet (SF-22-Z-B-III) Map, $1: 100,000$ scale. $=$ Levantamento Pedológico Semidetalhado do Estado de São Paulo: Quadrícula de Brotas (SF-22-Z-B-III). Instituto Agronômico, Campinas, SP, Brazil (in Portuguese).

Alvares, C.A.; Stape, J.L.; Sentelhas, P.C.; Gonçalves, J.L.M.; Sparovek, G. 2013. Koppen's climate classification map for Brazil. Meteorologische Zeitschrift 22: 711-728. DOI 10.1127/0941-2948/2013/0507.

Bagatini, T.; Giasson, E.; Teske, R. 2016. Expansion of pedological maps for physiographically similar areas by digital soil mapping. Pesquisa Agropecuária Brasileira 51: 1317-1325 (in Portuguese, with abstract in English).

Behrens, T.; Förster, H.; Scholten, T.; Steinrücken, U.; Spies, E.D.; Goldschmitt, M. 2005. Digital soil mapping using artificial neural networks. Journal of Plant Nutrition and Soil Science 168: 21-33.

Behrens, T.; Scholten, T. 2007. A comparison of data mining techniques in predictive soil mapping. p. 353-365. In: Lagacherie, P.; McBratney, A.; Voltz, M., eds. Digital soil mapping: an introductory perspective. Elsevier, Amsterdam, The Netherlands. (Developments in Soil Science, 31).

Breiman, L. 2001. Random forests. Journal of Machine Learning Research 45: 5-32.

Chagas, C.S.; Pinheiro, H.S.K.; Junior, W.C.; Anjos, L.H.C.; Pereira, N.R.; Bhering, S.B. 2017. Data mining methods applied to map soil units on tropical hillslopes in Rio de Janeiro, Brazil. Geoderma Regional 9: 47-55.

Cohen, J. 1960. A coefficient of agreement for nominal scales. Educational and Psychological Measurement 20: 37-46.

Crivelenti, R.C.; Coelho, R.M.; Adami, S.F.; Oliveira, S.R.M. 2009. Data mining for soil-landscape relationships inference in digital soil mapping. Pesquisa Agropecuária Brasileira 44: 1707-1715 (in Portuguese, with Abstract in English).

Dias, L.M.S.; Coelho, R.M.; Valladares, G.S.; Assis, A.C.C.; Ferreira, E.P.; Silva, R.C. 2016. Soil class prediction by data mining in an area of the São Francisco sedimentary basin. Pesquisa Agropecuária Brasileira 51: 1396-1404 (in Portuguese, with Abstract in English).

Fayyad, U.M.; Shapiro, G.P.; Smyth, P. 1996. From data mining to knowledge discovery: an overview. p. 1-34. In: Fayyad, U.M.; Piatetsky-Shapiro, G.; Smyth, P.; Uthurusamy, R., eds. Advances in knowledge discovery and data mining. American Association for Artificial Intelligence, Menlo Park, CA, USA.

Han, J.; Kamber, M.; Pei, J. 2011. Data Mining: Concepts and Techniques. Morgan Kaufmann, San Francisco, CA, USA.

Hastie, T.; Tibshirani, R.; Friedman, J. 2009. The Elements of Statistical Learning: Data Mining, Inference and Prediction. Springer, Stanford, CA, USA. (Springer Series in Statistics).

Hudson, B.D. 1992. The soil survey as paradigm-based science. Soil Science Society of America Journal 56: 836-841.

McBratney, A.B.; Santos, M.L.M.; Minasny, B. 2003. On digital soil mapping. Geoderma 117: 3-52.

Oliveira, J.B. 1999. Soils of the Piracicaba Sheet $=$ Solos da Folha de Piracicaba. Instituto Agronômico, Campinas, SP, Brazil (Boletim Científico, 48) (in Portuguese). 
Oliveira, J.B.; Prado, H. 1989. Semi detailed Soil Survey of the State of São Paulo: Piracicaba sheet (SF-23-Y-A-IV) Map, 1:100,000-scale. $=$ Carta Pedológica Semidetalhada do Estado de São Paulo: Piracicaba (SF-23-Y-A-IV). Instituto Agronômico, Campinas, SP, Brazil (in Portuguese).

Perrota, M.M.; Salvador, E.D.; Sachs, L.L.B. 2005. Geological Map of the State of São Paulo. 1:750,000-scale. = Mapa Geológico do Estado de São Paulo. CPRM-Serviço Geológico do Brasil, Brasília, DF, Brazil (in Portuguese).

Quinlan, J.R. 1993. C4.5: Programs for Machine Learning. Morgan Kaufmann, San Francisco, CA, USA.

Santos, H.G.; Jacomine, P.K.T.; Anjos, L.H.C.; Oliveira, V.A.; Lumbreras, J.F.; Coelho, M.R.; Almeida, J.A.; Cunha, T.J.F.; Oliveira, J.B. 2013. Brazilian System of Soil Classification. = Sistema Brasileiro de Classificação de Solos. 3ed. Embrapa, Brasília, DF, Brazil (in Portuguese).

Si, J.; Nelson, B.J.; Runger, G.C. 2003. Artificial neural network 410 models for data mining. p. 41-66. In: Ye, N., ed. The handbook of data mining. Lawrence Erlbaum, Mahwah, NJ, USA.

Silva, C.C.; Coelho, R.M.; Oliveira, S.R.M.; Adami, S.F. 2013. Digital soil mapping of the Botucatu sheet (SF-22-Z-B-VI-3): data training on conventional maps and field validation. Brazilian Journal of Soil Science 37: 846-857 (in Portuguese, with abstract in English).
Soil Survey Staff. 2014. Keys to Soil Taxonomy. 12ed. USDANatural Resources Conservation Service, Washington, DC, USA.

Ten Caten, A.; Dalmolin, R.S.D.; Ruiz, L.F.C. 2012. Digital soil mapping: strategy for data pre-processing. Revista Brasileira de Ciência do Solo 36: 1083-1091.

Ten Caten, A.; Dalmolin, R.S.D.; Pedron, F.A.; Ruiz, L.F.C.; Silva, C.A. 2013. An appropriate data set size for digital soil mapping in Erechim, Rio Grande do Sul, Brazil. Revista Brasileira de Ciência do Solo 37: 359-366.

Weiss, S.M.; Zhang, T. 2003. Performance analysis and evaluation. p. 425-440. In: Nong, Y., ed. The handbook of data mining. Lawrence Erlbaum, Mahwah, NJ, USA.

Witten, I.H.; Frank, E.; Hall, M.A.; Pal, C.J. 2016. Data Mining: Practical Machine Learning Tools and Techniques. Morgan Kaufmann, Burlington, MA, USA.

Zhou, Z.H. 2012. Ensemble Methods: Foundations and Algorithms. Chapman \& Hall, Cambridge, UK. 